\title{
EFEKTIFITAS MEDIA WHATSAPP GROUP DALAM PEMBELAJARAN DARING
}

\author{
Url Jurnal: https://uia.e-journal.id/akademika/article/1344 \\ DOI : https://doi.org/10.34005/akademika.v10i01.1344
}

Submitted: 2021-04-24

\author{
Khasanah \\ Universitas As-Syafi'iyah- \\ Indonesia \\ Khasanahrcl.mtp@uia.ac.id
}

Reviewed: 2020-09-18

Edy Nasan

SMK Dharma Bhakti Kota

Tangerang-Indonesia

edynasan73@gmail.com
Published: 2020-11-30

\author{
Jus'aini \\ Uin Sultan Maulana \\ Hasannudin Banten- \\ Indonesia \\ Jusaini.kamal@gmail.com
}

\begin{abstract}
WhatsApp has many features for sending messages, sending images, videos, sounds, creating groups and others and is easy to operate. The purpose of this study was to determine the effectiveness of online learning using WhatsApp media during the Covid-19 emergency in the subject of Islamic Religious Education. In an effort to reduce the spread of covid-19 in schools. The research subjects were PAI subject teachers, school principals and students of class XII accounting study program. This research uses descriptive qualitative research methods. The instruments used were interviews and questionnaires in the form of questions and statements aimed at respondents. Data was collected by means of interviews and questionnaires with google form. Data analysis was performed using Milles \& Huberman's interactive analysis techniques. The results showed that the application of online learning was carried out optimally in the sense that all Teaching and Learning Activities were carried out using an online system. The effectiveness of WhatsApp groups as a learning medium has not been fully effective, especially the lack of mastery of teachers in utilizing existing features. Weak supervision of students, teaching materials that students do not understand and the high cost of quotas are challenges in online learning.
\end{abstract}

Keywords: effectiveness, online learning, WhatsApp media.

Abstrak: WhatsApp memiliki banyak fitur pengiriman pesan, pengiriman gambar, video, suara, pembuatan grup dan lain-lain serta mudah dalam pengoperasiannya. Tujuan penelitian ini adalah untuk mengetahui efektifitas pembelajaran daring dengan menggunakan media WhatsApp pada masa darurat covid-19 pada mata pelajaran Pendidikan Agama Islam. Sebagai upaya menekan penyebaran covid-19 di sekolah. Subjek penelitian adalah guru mata pelajaran PAI, Kepala Sekolah dan siswa kelas XII Prodi akuntansi. Penelitian ini menggunakan metode penelitian deskriptif kualitatif. instrumen yang digunakan yaitu wawancara dan angket dalam bentuk pertanyaan dan pernyataan yang ditujukan untuk responden Data dikumpulkan dengan cara wawancara dan angket dengan google form. Analisis data dilakukan menggunakan teknik analisis interaktif Milles \& Huberman. Hasil penelitian menunjukkan bahwa penerapan pembelajaran daring dilaksanakan secara maksimal dalam arti semua Kegiatan Belajar Mengajar dilaksanakan dengan sistem daring. Efektifitas WhatsApp group sebagai media pembelajaran belum sepenuhnya efektif terutama kurangnya penguasaan guru dalam pemanfaatan fitur-fitur yang ada. Lemahnya pengawasan terhadap siswa, materi ajar yang kurang dipahami siswa dan mahalnya biaya kuota menjadi tantangan tersendiri dalam pembelajaran daring.

Kata Kunci: efektifitas, pembelajaran daring, media WhatsApp. 


\section{PENDAHULUAN}

Pandemi Corona Virus Disease 2019 (Covid-19) yang muncul di Indonesia pada bulan Februari 2020 masih terus menyebar secara meluas hingga saat ini. Hal ini berdampak pada berbagai sektor kehidupan, seperti: ekonomi, sosial budaya, pendidikan dan lainnya. Pemerintah telah mengambil sejumlah kebijakan untuk mencegah meluasnya penyebaran Covid-19, antara lain melalui pembatasan interaksi sosial dengan penerapan social distancing dan physical distancing, yaitu himbauan untuk menjaga jarak diantara masyarakat, menjauhi aktivitas dalam segala bentuk kerumunan, perkumpulan, dan menghindari adanya pertemuan yang melibatkan banyak orang (Rachmat \& Krisnadi, 2020).

Upaya tersebut ditujukan kepada masyarakat agar dapat dilakukan untuk memutus rantai penyebaran pandemi Covid-19 yang terjadi saat ini, mengurangi aktivitas di luar rumah dengan himbauan untuk beraktivitas di rumah saja, belajar dari rumah Anjuran ini kemudian dikuatkan dengan penerbitan Peraturan Pemerintah Nomor 21 Tahun 2020 tentang Pembatasan Sosial Berskala Besar (PSBB). (Daud, 2020). Kebijakan-kebijakan yang dikeluarkan untuk membatasi penyebaran virus corona berdampak pada berbagai bidang terkhusus pada bidang pendidikan (Herliandry et al., 2020). Pendidikan di Indonesia pun menjadi salah satu bidang yang terdampak akibat adanya pandemi Covid-19 tersebut. Dengan adanya pembatasan interaksi, Kementerian Pendidikan di Indonesia juga mengeluarkan kebijakan yaitu dengan meliburkan. sekolah dan mengganti proses Kegiatan Belajar Mengajar (KBM) dari sistem konvensional menjadi sistem dalam jaringan (daring). (Handarini \& Wulandari, 2020).

Pada tanggal 24 maret 2020 Menteri Pendidikan dan Kebudayaan Republik Indonesia mengeluarkan Surat Edaran Nomor 4 Tahun 2020 Tentang Pelaksanaan Kebijakan Pendidikan Dalam Masa Darurat Penyebaran Covid-19 (Anhusadar, 2020), Surat Edaran tersebut dikeluarkan sekaligus memberikan penegasan bahwa proses pembelajaran dilaksanakan di rumah melalui pembelajaran daring sebagai respons pendidikan yang menyikapi pandemi Covid-19 sebagai permasalahan serius yang dihadapi dunia. langkah ini diambil untuk memutus mata rantai penularan Covid-19 antar komponen pendidikan. Oleh karena itu, pembelajaran daring dapat dikatakan menjadi jalan tengah yang dapat dilakukan oleh pendidik untuk meningkatkan mutu pembelajaran di Indonesia. Sejak saat itu, proses pembelajaran di kelas beralih pada pembelajaran daring.

Pada tataran pelaksanaanya pembelajaran daring memerlukan dukungan perangkat-perangkat mobile seperti smarphone atau telepon adroid, laptop, komputer, tablet, dan iphone yang dapat dipergunakan untuk mengakses informasi kapan saja dan dimana saja (Suhendra et al., 2020).

Dalam pembelajaran daring tidak terlepas dari penggunaan sekaligus pemanfaatan media. Pemanfaatan media pada dasarnya dimaksudkan untuk membantu agar kegiatan pembelajaran lebih efektif mencapai tujuan dan efisien dalam hal tenaga, waktu dan biaya (Hayes et al., 2017). Ada banyak media yang digunakan untuk belajar daring. Berbagai platform sudah lama menyediakan jasa ini. Sebut saja misalnya Google Clasroom, Rumah Belajar, Edmodo, Ruang 
Guru, Zenius, Google Suite for Education, Microsoft Office 365 for Education, Sekolahmu, Kelas Pintar. Inilah yang disebut sebagai platform microbloging (Mirzon Daheri, Juliana, Deriwanto, 2020) Namun perlu waktu untuk mempelajari sistem belajar melalui platform belajar daring tersebut. Maka guru harus bisa menggunakan berbagai media yang familiar digunakan siswa. Harapannya untuk tidak mempersulit siswa dalam penggunaan media tersebut agar Proses belajar tetap berjalan. Salah satunya media sosial WhatsApp.

WhatsApp merupakan salah satu alternatif pilihan media pembelajaran yang sangat tepat, bila dibandingkan dengan media pembelajaran online lainnya, hal tersebut dikarenakan WhatsApp adalah aplikasi yang sangat sederhana, WhatsApp memiliki banyak fitur seperti untuk kirim pesan, kirim gambar, video, suara, buat grup dan lain-lain serta mudah dalam pengoperasiannya.(Di \& Nurulhuda, 2020).

Hasil riset terdahulu mengenai pembelajaran daring dengan menggunakan media WhatsApp group ini pernah dilakukan oleh beberapa peneliti. Berdasarkan data terbaru E. Susilowati (2020) yang menyatakan bahwa pembelajaran daring dapat dilakukan melalui grup WhatsApp dengan model pembelajaran Group Discussion By WhatsApp dalam meningkatkan kemandirian belajar mahasiswa disimpulkan efektif. Demikian juga Di \& Nurulhuda (2020) menemukan bahwa pemanfaatan whatshapp sebagai media pembelajaran ditengan pandemi covid 19 seperti saat ini sangatlah tepat, mengingat aplikasi ini sangat sederhana bila dibandingkan dengan aplikasi online lainnya, mudah dalam pengoperasiannya dan tentunya memiliki fitur-fitur yang banyak. Selain sebagai media pembelajaran pemanfaatan WhatsApp dalam aktivitas edukasi bertujuan sebagai sarana edukasi, sebagai sarana evaluasi, sebagai sarana penyambung informasi, dan sebagai sarana layanan konsultasi dan menjalin silaturahim (Wahyuni, 2018).

Melihat hasil penelitian yang telah dilakukan menunjukkan bahwa WhatsApp memiliki fitur yang mendukung untuk menjadi media pendukung dalam proses belajar mengajar, WhatsApp juga membantu mempermudah pekerjaan guru yang tidak masuk kelas saat ada tugas luar atau rapat yang tidak bisa ditinggalkan, siswa yang tidak masuk juga bisa mengirim tugas lewat WhatsApp kepada guru yang bersangkutan.

Peneliti tertarik melakukan penelitian ini untuk memperoleh informasi lanjutan mengenai penerapan pembelajaran daring dan efektivitas WhatsApp group sebagai media pembelajaran daring selama masa darurat Covid-19 pada mata pelajaran PAI di SMK Dharma Bhakti Kota Tangerang. Ingin melihat apakah efektif juga media WhatsApp ini jika dijadikan media belajar pada mata pelajaran PAI di wilayah yang berbeda yaitu di Tangerang. Dengan banyaknya penelitian terkait WhatsApp di berbagai propinsi di Indonesia, diharapakan menjadi penguat penggunaan media ini dalam pembelajaran di masa Covid-19, sehingga WhatsApp yang demikian populernya di Indonesia menjadi solusi dalam pembelajaran daring secara efektif.

\section{METODE}

Penelitian ini menggunakan metode kualitatif, yang digunakan untuk meneliti pada kondisi objek alamiah dimana peneliti adalah sebagai instrumen 49 | Akademika | Vol 10 | No. 1 | 2021 
kunci (Riduwan, 2018). Dengan metode ini diharapkan dapat mengidentifikasi penerapan pembelajaran daring. dengan menggunakan media WhatsApp group selama darurat Covid-19 pada pembelajaran Pendidikan Agama Islam, sebagai upaya mendukung program pemerintah yaitu study from home selama darurat Covid 19. Penelitian dilakukan dengan menyebarkan angket (kuesioner) kepada siswa. Angket (kuesioner) dilaksanakan menggunakan google form yang tautannya disebarkan melalui applikasi WhatsApp. Terdapat 22 siswa yang memberikan tanggapan terhadap angket (kuesioner) yang dilakukan.

Setelah semua data terkumpul melalui kepustakaan lalu data tersebut diklasifikasikan dan ditelaah, dengan menggunakan data deskriptif ini membicarakan beberapa kemungkinan untuk memecahkan masalah yang aktual, dengan menggumpulkan data, menyusun dan mengkasifikasinya, menganalisa kemudian menginterpretasikannya. Fungsi analisis data adalah mengumpulkan fakta-fakta khusus dilapangan kemudian di deskripsikan secara mendetail lalu dikorelasikan dengan teori-teori efektifitas pembelajaran daring (online) dan ditarik menjadi sebuah kesimpulan umum.

Untuk analisis menggunakan bentuk prosentase dalam mencari skor masing-masing dengan menggunakan rumus $P=F / N \times 100 \%$. $P$ adalah Prosentase, $\mathrm{F}$ adalah Frekuensi jawaban responden, $\mathrm{N}$ adalah Number of Cases (Jumlah Responden).

Sebagai upaya untuk memeriksa keabsahan data, peneliti menggunakan beberapa teknik sebagai mana dikemukakan oleh Moleong, yaitu dengan Teknik ketekunan, yakni peneliti secara tekun memusatkan diri pada latar penelitian untuk menemukan ciri-ciri dan unsur yang relevan dengan persoalan yang diteliti peneliti mengamati langsung penerapan pembelajaran daring dengan menggunakan media online pada mata pelajaran pendidikan agama Islam pada kelas XII program studi Akuntansi.

Teknik mengecek keabsahan data lainnya adalah dengan triangulasi, yaitu teknik yang mana peneliti memanfaatan sumber lain diluar data untuk keperluan pengecekan dalam hal ini ada dua metode triangulasi yang digunakan untuk pemeriksaan data (1) triangulasi metode dan pengumpulan data, (2) triangulasi data dengan pengecekan yang dibantu oleh teman sejawat, dosen pembimbing serta pihak-pihak lain yang memahami penelitian ini.

Penyajian data dengan kecukupan referensi dilakukan dengan membaca dan menelaah sumber-sumber data dan sumber-sumber lain yang relevan dengan masalah penelitian ini secara berulang-ulang agar diperoleh pemahaman yang memadai.

\section{HASIL}

Berdasarkan data yang diperoleh dari hasil wawancara dengan kepala SMK Dharma Bhakti Kota Tangerang tentang Penerapan pembelajaran daring serta efektivitas WhatsApp group sebagai media pembelajaran daring selama masa darurat Covid-19 di SMK Dharma Bhakti Kota Tangerang. Penerapan pembelajaran daring selama masa darurat Covid-19 dilakukan secara daring dan dalam pelaksanaannya dilakukan secara maksimal dalam arti semua KBM dilakukan secara daring. 
Ada banyak media yang digunakan untuk pembelajaran daring. Berbagai platform sudah lama menyediakan jasa ini. Sebut saja misalnya Google Clasroom, Rumah Belajar, Edmodo, Ruang Guru, Zenius, Google Suite for Education, Namun perlu waktu untuk mempelajari sistem belajar melalui platform belajar daring tersebut. Namun, guru belum tentu paham penggunaan media ini. Apalagi orang tua dengan berbagai latar belakangnya. Disinilah problem itu tidak ada waktu lagi untuk mempelajari semuanya bersama sama. Covid-19 memaksa semuanya untuk tetap di rumah. Guru harus bisa menggunakan berbagai media yang familiar digunakan. Harapannya tidak mempersulit siswa dalam penggunaan media tersebut dan proses KBM tetap berjalan. Salah satunya media sosial WhatsApp.

Berdasarkan hasil angket yang dilakukan peneliti terhadap responden dengan menggunakan aplikasi goole form yang tautannya dikirim ke group para guru dan siswa. Diperoleh beberapa hal berikut :

\section{Para guru pengguna WhatsApp}

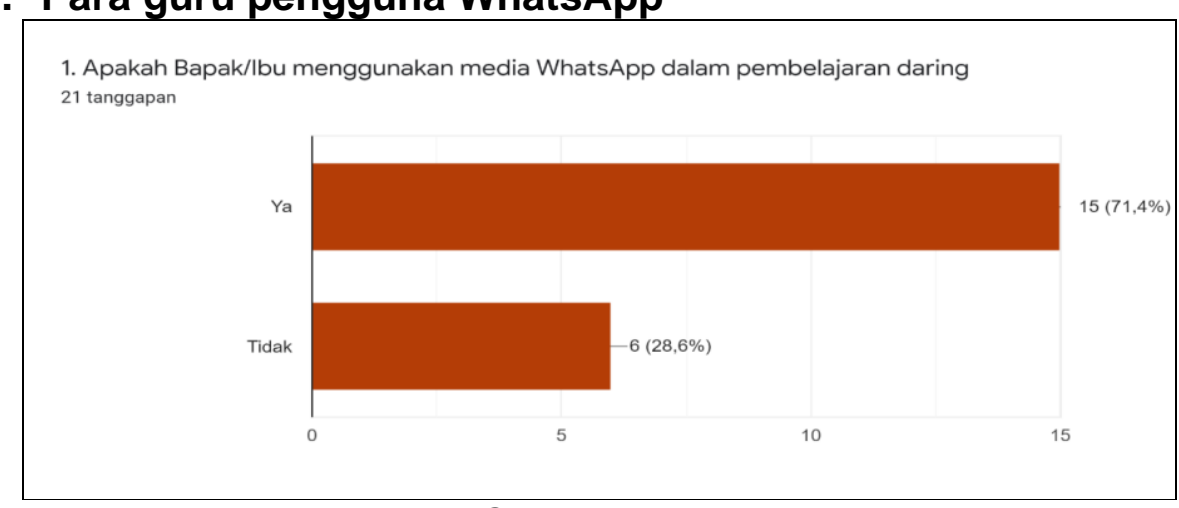

Gambar 1. Guru Pengguna WhatsApp

Dari 21 orang guru menjawab sebanyak $15(71,4 \%)$ orang guru adalah pengguna WhatsApp dalam proses pembelajaran dan $6(28,6 \%)$ orang guru tidak menggunakan WhatsApp dalam pembelajaran. Ini artinya mayoritas guru lebih memilih WhatsApp sebagai media pembelajaran daring.

\section{Kesiapan siswa dalam pembelajaran daring}

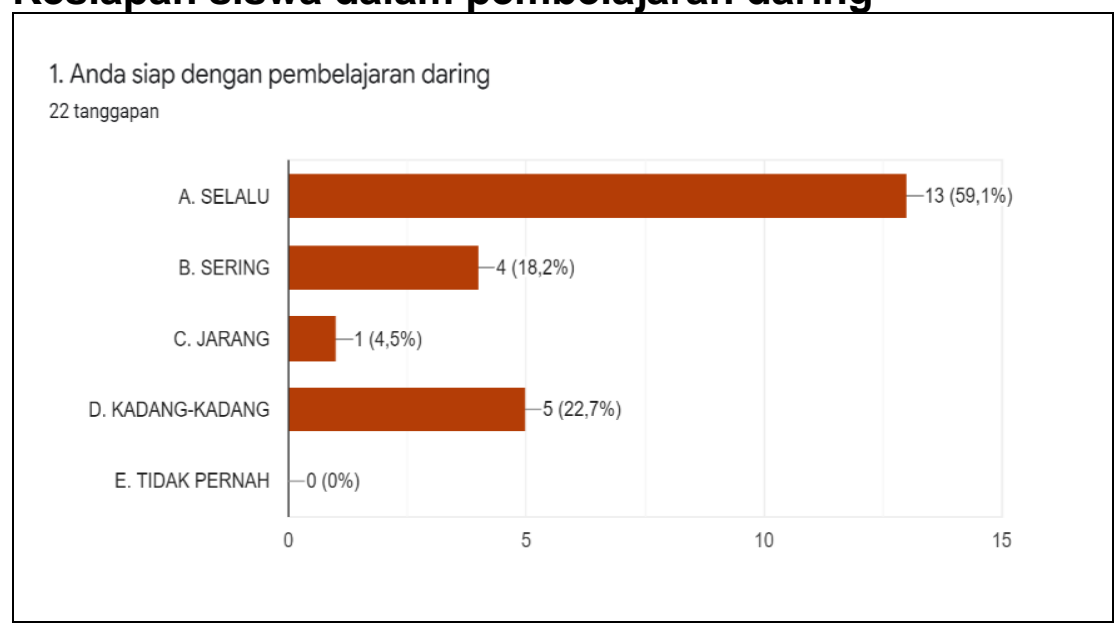

Gambar 2. Kesiapan Pembelajaran Daring

Berdasarkan tabel di atas, dapat dilihat bahwa sebanyak 13 orang (59\%) menjawab selalu, 4 orang $(18.2 \%)$ siswa menjawab sering, 1 orang $(4,5 \%)$ menjawab jarang dan 5 orang $(22,7 \%)$. Ini artinya sudah banyak peserta didik 
yang mempersiapkan dirinya untuk mengikuti pembelajaran daring selama masa pandemi ini, namun tidak menutup kemungkinan bahwa ada beberapa peserta didik yang memang belum siap mengikuti pembelajaran daring ini.

3. Sarana pendukung pembelajaran daring

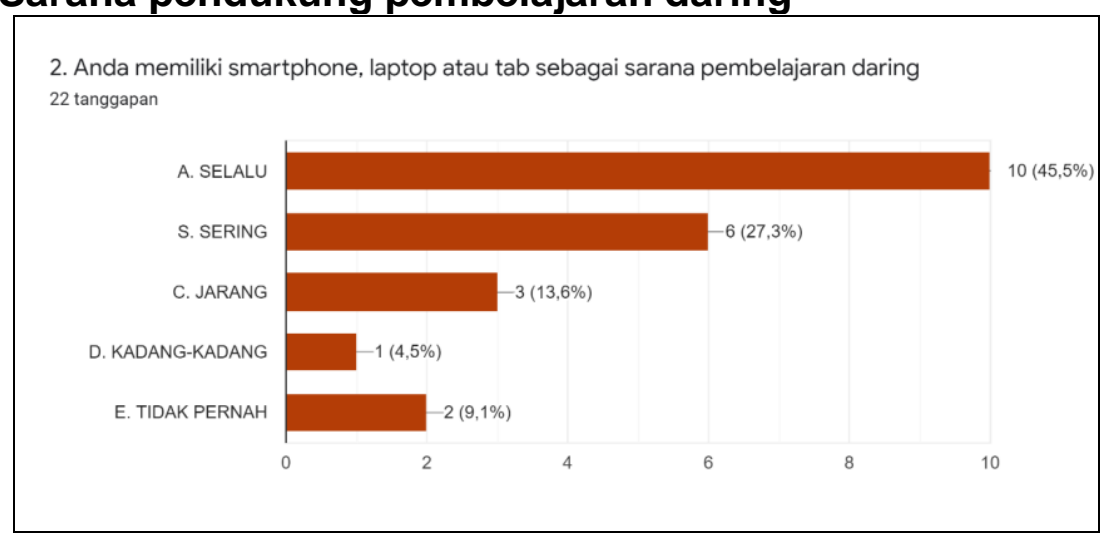

Gambar 3. Sarana Pembelajaran Daring Siswa

Dari gambar 3 tersebut, dapat dilihat bahwa $45,5 \%$ atau 10 orang siswa menjawab selalu , $27,3 \%$, atau 6 orang siswa menjawab sering, $13,6 \%$ atau 3 orang siswa menjawab jarang, 4,5\% atau 1 orang siswa menjawab kadangkadang dan $9,1 \%$ atau 2 orang siswa menjawab tidak pernah. $61,7 \%$ responden menyatakan dirinya selalu memiliki laptop, smartphone, dan internet sebagai media dalam pembelajaran daring. Ini berarti pembelajaran daring dapat diterapkan karena peserta didik sudah memiliki media pembelajaran yang dapat mendukung proses pembelajaran daring selama masa pandemi ini.

\section{Pemahaman materi ajar}

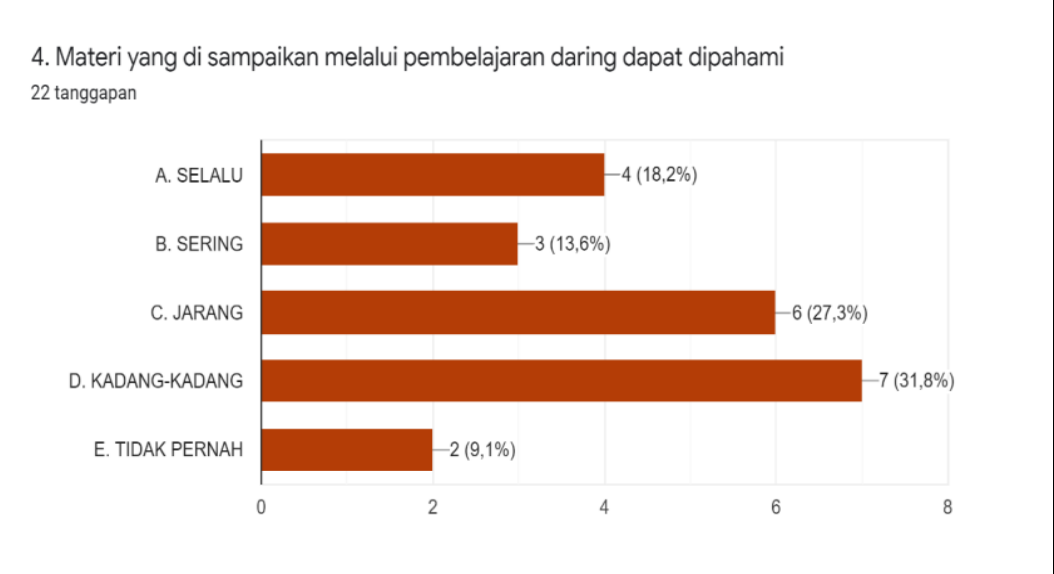

Gambar 4. Pemahaman Materi Ajar

Kemudian dari sisi pemahaman peserta didik apakah mereka memahami materi yang dijelaskan dengan menggunakan pembelajaran daring, hasilnya kurang baik karena sebagian besar dari mereka 4 orang siswa ( $18,2 \%)$, menjawab selalu, 3 orang siswa atau ( 13,6 \%) menjawab sering, 6 atau ( 27,3 $\%$ ) orang siswa menjawab jarang, kadang-kadang 7 ( $31,6 \%)$ orang siswa dan 2 atau $(9,1 \%)$ orang siswa menjawab tidak pernah.

\section{Kendala selama pembelajaran daring}




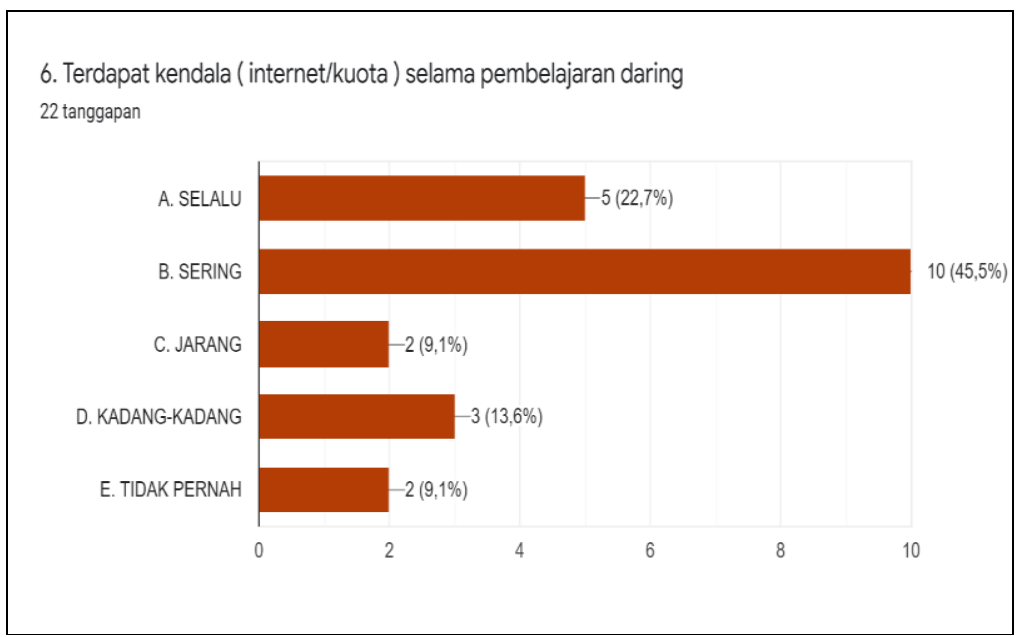

Gambar 5. Kendala selama pembelajaran daring

Pembelajaran daring memerlukan fasilitasi seperti Smartphone atau laptop, tetapi ada sebagian siswa yang tidak memiliki Smarthpnone atau laptop ditambah lagi tidak adanya kuota internet untuk melakukan pembelajaran secara daring ini menjadi masalah besar bagi siswa.. Dari total responden 22 orang yang menjawab selalu sebanyak $5(22,7 \%)$ yang menjawab sering sebanyak 10 $(45,5 \%)$, jarang $2(9,1 \%)$, kadang-kadang $3(13,6 \%)$ dan tidak pernah sebanyak $2(9,1 \%)$. Dapat disimpulkan kendala terbesar pada siswa selama pembelajaran daring adalah kurang suport kuota.

Kendala ini menjadi hal yang utama juga bagi efektiiftas penggunaan media WhatsApp Grub juga di SMK ini, karena menurut Suhendra Pada tataran pelaksanaanya pembelajaran daring memerlukan dukungan perangkatperangkat mobile seperti smarphone atau telepon adroid, laptop, komputer, tablet, dan iphone yang dapat dipergunakan untuk mengakses informasi kapan saja dan dimana saja (Suhendra et al., 2020). Tentu di harus di support dengan kuota internet yang cukup.

Pembelajaran daring dapat diartikan sebagai suatu pembelajaran yang dalam pelaksanaannya menggunakan jaringan internet, intranet dan ekstranet atau komputer yang terhubung langsung dan cakupannya global (Bilfaqih \& Qomarudin, 2015) Pembelajaran daring dipilih sebagai jalan tengah untuk mengurangi potensi penyebaran virus covid-19. Walaupun dikatakan oleh Bilfaqih \& Qamruddin (2016) pembelajaran daring mampu memberikan layanan yang menarik dan meningkatkaan efektifitas pembelajaran, akan tetapi tetap saja dalam pelaksanaanya memiliki tantangan sendiri.

\section{Penggunaan Media WhatsApp oleh Guru Sebagai Media Pembelajaran Daring}

Dapat dilihat pada tabel berikut: 


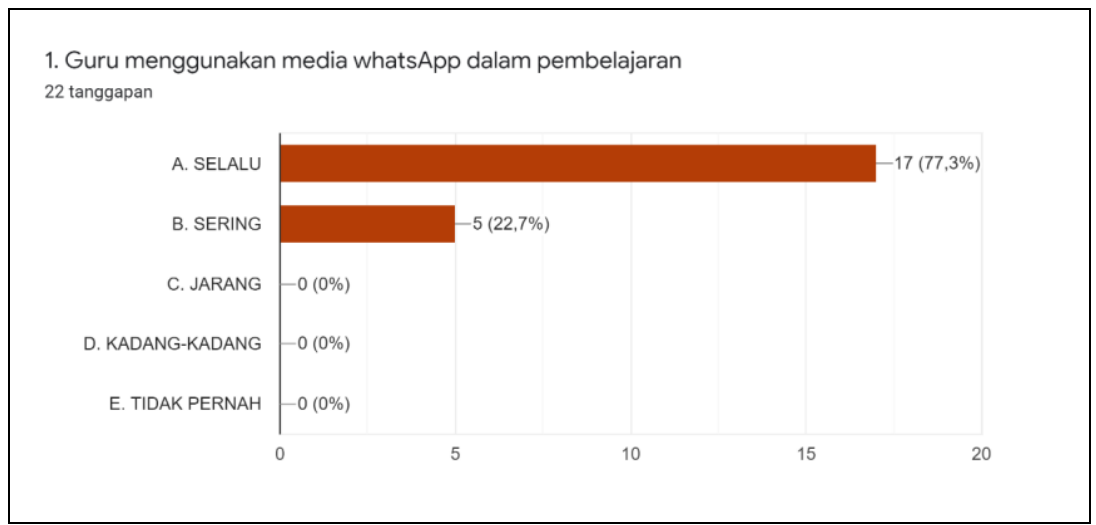

Gambar 6. Penggunaan Media WhatsApp dalam Pembelajaran

Salah satu aplikasi yang sering digunakan dalam proses pembelajaran adalah WhatsApp. Para siswa baik dari pendidikan formal maupun non formal di Indonesia pada era digital ini sudah menggunakan aplikasi ini dalam aktivitas keseharian mereka baik di sekolah maupun di luar sekolah. Sehingga para siswa tidak banyak mengalami kesulitan dalam mengikuti pembelajaran daring yang diberikan oleh guru melalui aplikasi WhatsApp ini dibanding menggunakan aplikasi lainnya. Guru biasanya akan memberikan materi dan penjelasan melalui WhatsApp grup kelas yang dibuat oleh wali kelasnya. Guru juga mengirimkan materi pelajaran dalam bentuk misalnya video, pesan suara (voice note), atau berupa file (power point atau ms. word). Untuk penugasan guru biasanya menyuruh siswa melakukan atau membuat sesuatu yang kreatif dengan menggunakan media WhatsApp. Dari hasil angket pada point ini, yang menjawab selalu sebanyak 17 orang siswa $(77,3 \%)$, yang menjawab sering 5 orang siswa $(22,7 \%)$, dan yang menjawab jarang, kadang-kadang dan tidak pernah nihil ( $0 \%)$. Dapat disimpulkan bahwa guru dalam memberikan pelajaran selalu dan sering menggunakan media WhatsApp. Hal ini dapat dilihat pada tabel di atas.

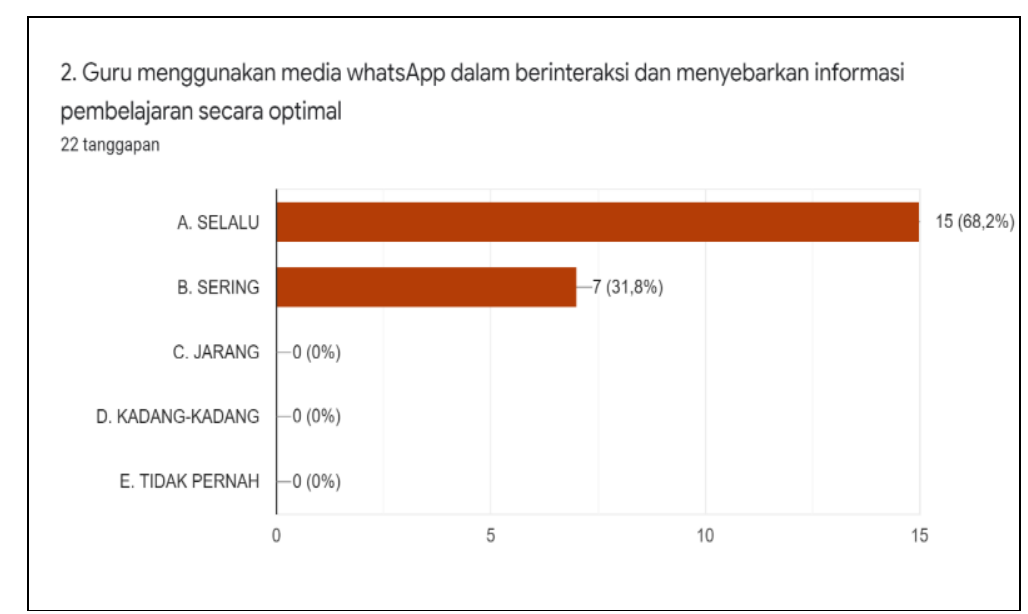

Gambar 7. Optimalitas Penggunaan WhatsApp dalam Pembelajaran

Salah satu usaha untuk beradaptasi dengan perubahan zaman adalah optimalisasi penggunaan Teknologi, Informasi, dan Komunikasi (TIK) dalam kegiatan pembelajaran. Optimalisasi penggunaan sarana TIK ini diharapkan dapat mempersiapkan guru masa depan yang melek teknologi serta siap berperan dalam dunia yang semakin sempit dengan perkembangan TIK. 
Sebagai pendidik masa depan, sudah sepatutnya seorang pendidik mampu memanfaatkan segala yang tersedia dan berusaha mengubah potensi negatif menjadi bermanfaat dalam bidang pendidikan. Potensi inilah yang dapat ditemukan dalam media sosial yang sudah menjamur bahkan mempengaruhi pola pikir masyarakat. Salah satu media sosial yang sudah cukup menjamur bahkan hampir semua masyarakat telah menggunakannya adalah aplikasi WhatsApp. Dari 22 responden dan hasil angket yang diperoleh, yang menjawab selalu sebanyak 15 orang siswa (68,2\%) dan 7 orang siswa ( $3,8 \%$ ) menjawab sering serta yang menjawab jarang, kadang-kadang dan tidak pernah nihil ( $0, \%)$. Dapat disimpulkan secara garis besar siswa mendapatkan kemudahan baik dalam berinteraksi maupun mengakses informasi dengan media WhatsApp. Hal ini dapat terlihat pada tabel di atas.

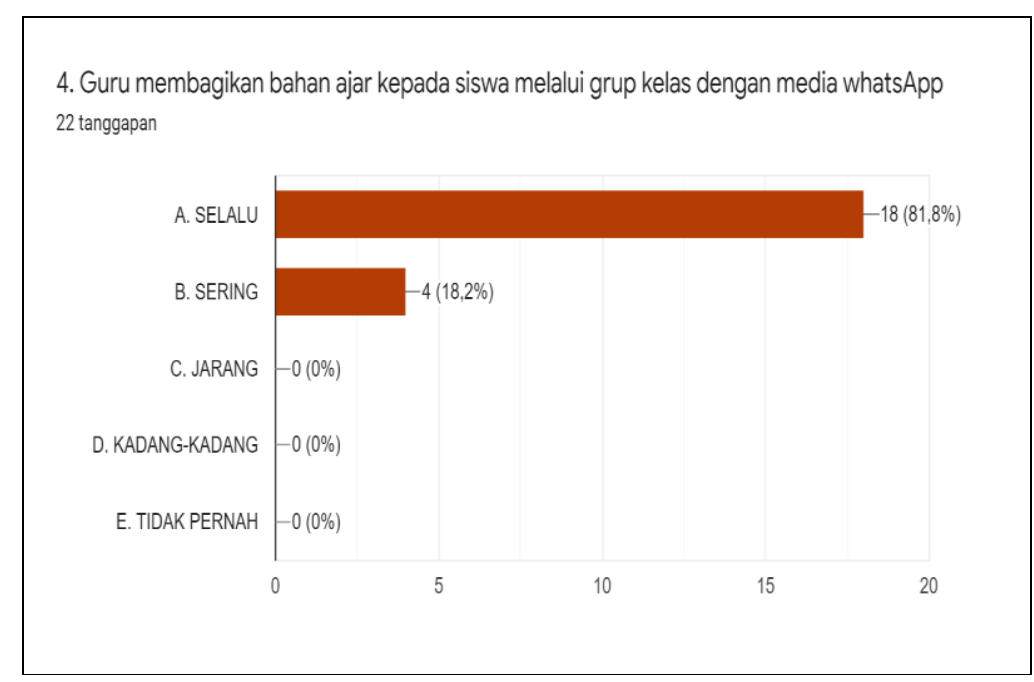

Gambar 8. Membagikan bahan ajar dengan WhatsApp

Media WhatsApp grup digunakan oleh lembaga pendidikan dari berbagai jenjang, Para pendidik harus memberikan pengajaran dengan konsep baru, serta cara jitu dalam mengontrol para peserta didik melalui WhatsApp group kelas yang dibuat oleh wali kelas. Dari hasil angket yang terjawab, pada point ini yang menjawab selalu $18(81,8 \%)$, sering $4(18,2 \%)$, jarang dan kadang-kadang serta tidak pernah $0(0,0 \%)$. Dapat dikatakan bahwa dalam pemberian bahan ajar WhatsApp group menjadi medianya. Hal ini dapat dilihat pada tabel di atas 


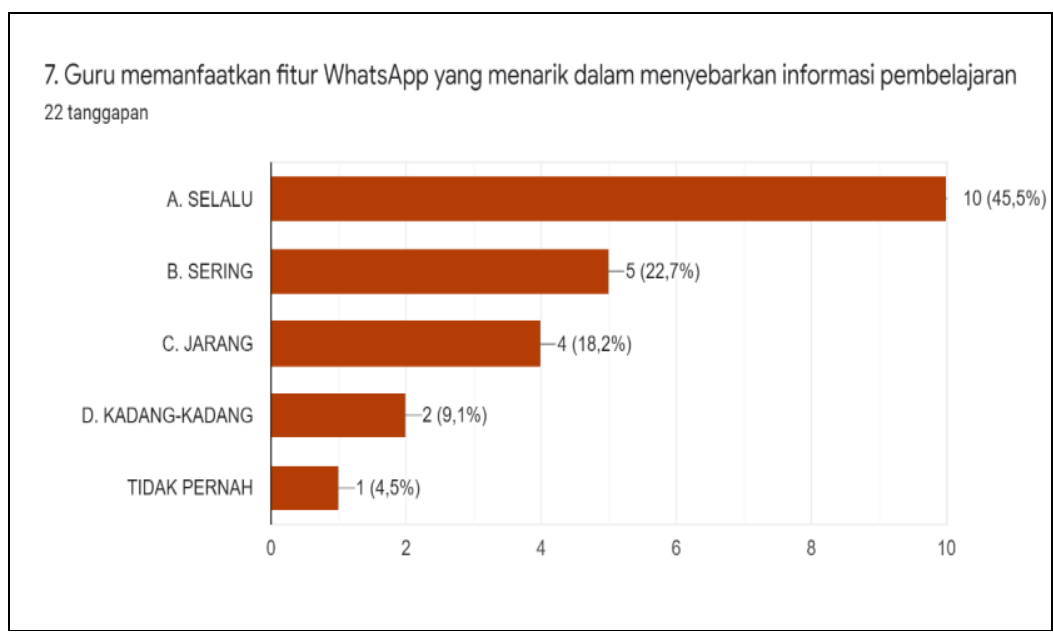

Gambar 9. Pemanfaatkan Fitur WhatsApp Oleh Guru
Fitur-fitur yang terdapat dalam WhatsApp yaitu Gallery untuk menambahkan foto, Contact untuk menyisipkan kontak, Camera untuk mengambil gambar, Audio untuk mengirim pesan suara, Maps untuk mengirimkan berbagai koordinat peta, bahkan Document untuk menyisipkan file berupa dokumen. Semua file tersebut dapat dalam sekejap dikirim melaui aplikasi gratis tersebut. Berbagai fitur tersebut tentu semakin menambah kemudahan dan kenyamanan berkomunikasi melalui media online. Dari hasil angket yang terjawab, dapat dibuktikan siswa yang menjawab selalu 10 (46,5\%), sering 5 (22.7\%), sedangkan yang menjawab jarang 4 (18,2\%), kadang-kadang $2(9,1 \%)$ dan tidak pernah $1(4,5 \%)$. Dapat di simpulkan proses pembelajaran guru senantiasa memanfaatkan fitur-fitur yang ada di media WhatsApp. Hal ini dapat dilihat pada tabel di atas

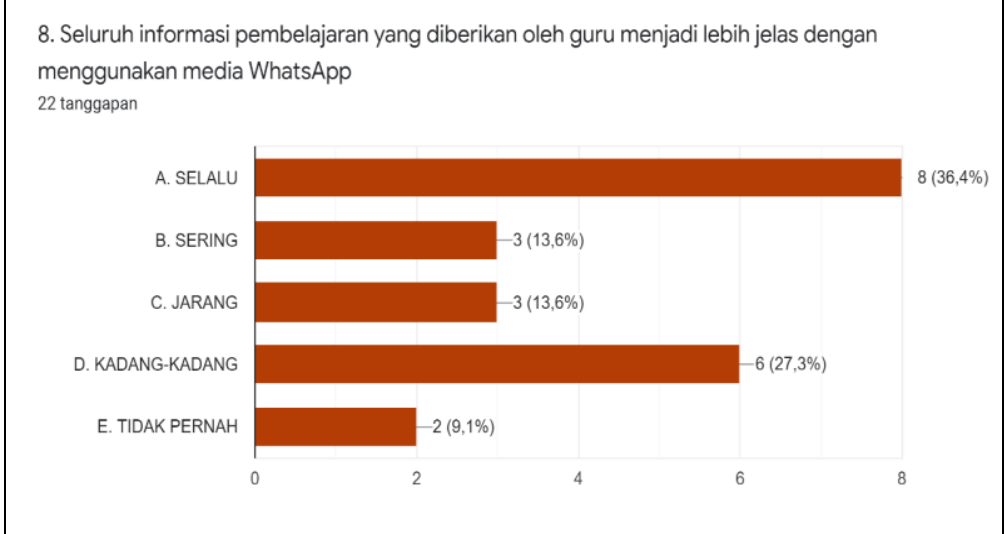

Gambar 10. Informasi yang Diberikan Guru Lebih Jelas dengan WhatsApp

Pengaruh media sosial pada era teknologi menjadikan ketergantungan masyarakat kepada komunikasi dan interaksi melalui media sosial daripada bertemu secara langsung. Media sosial memungkinkan penggunanya untuk saling bersolialisasi dan berinteraksi, berbagi informasi maupun menjalin kerja sama. Diantara berbagai jenis media sosial yang memudahkan pengguna untuk saling berinteraksi dan berkomunikasi, serta dapat digunakan sebagai forum diskusi dan penyebaran materi pembelajaran salah satunya ialah WhatsApp. Keberadaan WhatsApp cukup potensial untuk penyebaran informasi. Dari hasil angket yang diperoleh bahwa siswa yang menjawab selalu $8(36,4 \%)$, sering 
dan jarang berbanding3 (13,6\%), kadang-kadang 6 (27,3\%) dan tidak pernah 2 $(19,1 \%)$. Dapat disimpulkan bahwa di dalam penyampaian informasi pembelajaran guru menggunakan WhatsApp. Hal ini dapat dilihat pada tabel di atas.

Adapun hasil belajar yang di dapat dari Penilaian Akhir Semester (PAS) semester ganjil kelas XII Akuntansi SMK Dharma Bhakti tahun pelajaran 20202021, kemudian di bandingkan dengan sebelum menggunakan media WhatsApp Grub terlihat pada diagram berikut:

\section{Grafik Nilai PAS Mapel PAI Kelas XII.AK Sebelum dan Ketika Daring}

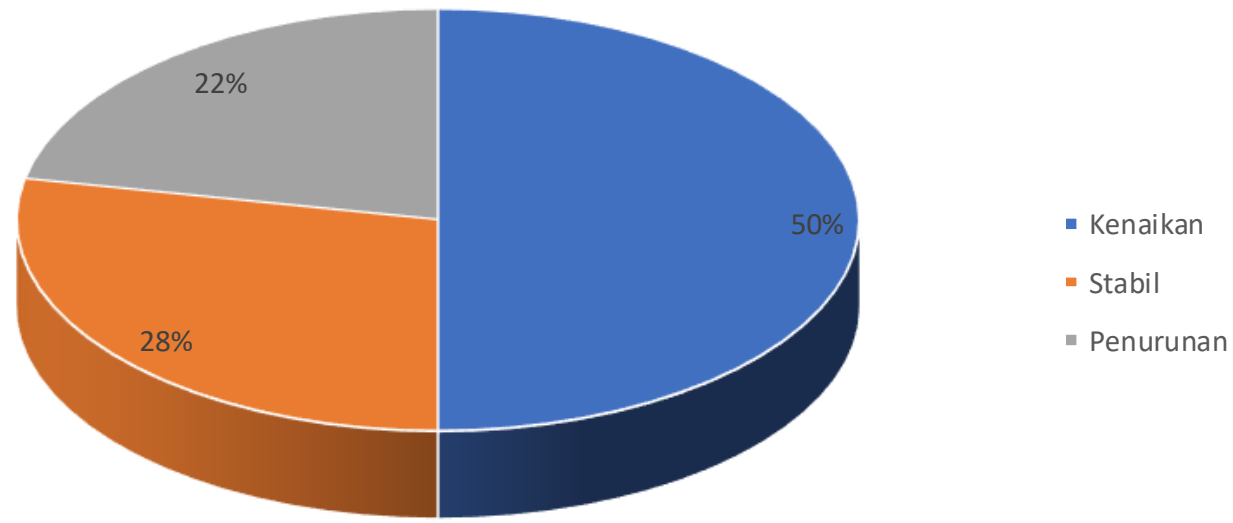

Gambar 1. Nilai Siswa

Dari Diagram 1 di atas terlihat bahwa nilai siswa selama masa Covid-19 ini, lebih meningkat 50\% menggunakan WhatsApp di bandingkan dengan tanpa menggunakan WhatsApp. Meskipun dalam angket yang diisi oleh siswa menyatakan bahwa mereka mendapatkan kendala kuota internet dalam pembelajaran daring, namun media ini tetap lebih efektif bagi mereka di bandingkan dengan media lain, seperti zoom meeting yang kuota internetnya tentu lebih besar lagi.

\section{PEMBAHASAN}

Penelitian yang menghasilkan beberapa temuan di atas dapat di bahas sebagi berikut:

\section{Penerapan pembelajaran daring dengan menggunakan WhatsApp di SMK Dharma Bhakti Kota Tangerang}

Berdasarkan data yang diperoleh dari hasil wawancara dengan kepala SMK Dharma Bhakti Kota Tangerang Penerapan pembelajaran daring di SMK Dharma Bhakti Kota Tangerang selama masa darurat Covid-19 dilakukan secara daring dan dalam pelaksanaannya dilakukan secara maksimal dalam arti semua KBM dilakukan secara daring terutama dengan bantuan media WhatsApp. hal ini didukung oleh data pada gambar 1 di atas bahwa dari 21 orang guru yang mengajar, sebanyak $15(71,4 \%)$ orang guru adalah pengguna WhatsApp dalam proses pembelajaran dan $6(28,6 \%)$ orang guru tidak menggunakan WhatsApp 
dalam pembelajaran. Ini artinya mayoritas guru lebih memilih WhatsApp sebagai media pembelajaran daring.

Aktivitas belajar tetap dilaksanakan dengan bantuan WhatsApp meskipun adanya jarak pemisah antara pendidik dan peserta didik. Pemanfaatkan kecanggihan teknologi informasi dan pembelajaran pun dilakukan dengan daring. Hal ini tepat sekali tentunya, sebagaimana yang diungkapkan oleh Ely, dalam Kahirul Umam (2014), bahwa potensi teknologi pendidikan dapat (1) meningkatkan produktivitas pendidikan dengan mempercepat tahap belajar, (2) memberikan kemungkinan pelajar untuk belajar secara mandiri, (3) memberikan dasar yang lebih ilmiah terhadap pembelajaran, (4) lebih memantapkan pembelajaran, (5) memungkinkan untuk belajar (mengakses materi) dengan cepat, dan (6) memungkinkan penyajian pembelajaran yang lebih luas (Padmini \& Tyagita, 2015).

Dalam pembelajaran daring guru di SMK Dharma Bhakti Kota Tangerang telah membuat bahan pembelajaran yang baik dan bagus dan menerangkan pembelajaran dengan cermat agar peserta didik dapat mengerti. Bukan hanya mengajar, guru juga memerhatikan kesiapan dan kesediaan peserta didik untuk mendengar pembelajaran. Persiapan siswa mengikuti pembelajaran daring ini berada pada tataran 59\% (lihat gambar 2 di atas) artinya siswa SMK Dharma Bhakti merespons kondisi yang ada, persiapan guru dengan materi yang ada menarik Sebagian siswa untuk terus mengikuti pembelajaran.

Kita ketahui bahwa pada hakekatnya fungsi media sebagai alat bantu dalam kegiatan belajar yakni berupa sarana yang dapat memberikan pengalaman visual kepada siswa dalam rangka mendorong motivasi belajar memperjelas dan mempermudah konsep yang kompleks dan abstrak menjadi lebih sederhana, konkrit, serta mudah dipahami. Hal tersebut di atas diungkapkan oleh (Asnawir dan M. Basyirudin U, 2002). Dan Media pembelajaran sangat diperlukan oleh guru untuk membantu menyampaikan materi dalam sebuah proses pembelajaran. Peserta didik cenderung lebih tertarik dan mudah memahami apabila proses pembelajarannya menggunakan sebuah animasi serta peserta didik akan lebih mudah dalam mengingatnya dan dapat memaksimalkan hasil belajar yang dicapai.

Dari ungkapan ahli di atas terlihat bahwa seharusnya materi yang di siapkan oleh guru SMK ini, selaykanya dengan tampilan menarik, tidak membuat siswa malas mengikuti pelajaran dan mengerjakan tugas . dari informasi di atas terlihat siswa masih ada yang malas mengerjakan tugas dan malas-malasan menguikuti materi, bisa jadi karena tampilan materinya tidak menarik, tidak disertai animasianimasi misalnya.

Pemanfaatan media pada dasarnya dimaksudkan untuk membantu agar kegiatan pembelajaran lebih efektif mencapai tujuan dan efisien dalam hal tenaga, waktu dan biaya (Iwan Falahudin, 2014). Media pembelajaran online merupakan suatu jenis belajar mengajar yang memungkinkan tersampaikannya bahan ajar ke siswa dengan menggunakan media Internet. Media pembelajaran online sebagai sebuah alternatif pembelajaran yang berbasis elektronik memberikan banyak manfaat terutama terhadap proses pendidikan yang dilakukan dengan jarak jauh. Dalam membuat media pembelajaran online perlu mempertimbangkan harapan dan tujuan mereka dalam mengikuti media pembelajaran online, kecepatan dalam mengakses internet atau jaringan, 
keterbatasan bandwidth, biaya untuk akses internet, serta latar belakang pengetahuan yang menyangkut kesiapan dalam mengikuti pembelajaran (Nurita Putranti, 2013)

Media pembelajaran pada pembelajaran daring digunakan sebagai alat untuk meningkatkan efesiensi dan efektivitas pembelajaran. Media pemebelajaran dipergunakan untuk mencapai tujuan seperti membuat jelas pesan secara visual sehingga tidak terlalu verbal. Mengatasi keterbatasan ruang, waktu dan lima indera. Mempercepat proses belajar dan mengajar, menimbulkan semangat dalam belajar, memberikan kesempatan bagi perserta didik untuk berinteraksi langsung dengan lingkungan mereka dan kenyataan di lapangan, serta memberikan kesempatan kepada peserta didik untuk belajar mandiri berdasarkan kemampuan dan minat mereka (Ni Nyoman Padmadewi, dkk. 2017)

Pada tataran pelaksanaanya pembelajaran daring di di SMK Dharma Bhakti Kota Tangerang memerlukan dukungan perangkat-perangkat mobile seperti smarphone atau telepon adroid, laptop, komputer, tablet, dan iphone yang dapat dipergunakan untuk mengakses informasi kapan saja dan dimana saja. Terutama saat berkomunikasi dengan anak didik maka WhatsApp sangat membutuhkan hal ini. Selain adanya faktor yang pendukung dalam pembelajaran daring di di SMK Dharma Bhakti Kota Tangerang. Juga siswa bekerjasama dengan menyiapkan perangkat pendukung untuk belajar. Sesuai data pada gambar 3 di atas yang didapatkan bahwa 61,7\% responden menyatakan dirinya selalu memiliki laptop, smartphone, dan internet sebagai media dalam pembelajaran daring. Ini berarti pembelajaran daring dapat diterapkan karena peserta didik sudah memiliki media pembelajaran yang dapat mendukung proses pembelajaran daring selama masa pandemi ini. Meskipun demikian terdapat juga beberapa faktor penghambat yang ada dalam pembelajaran daring.

Hal ini terjadi karena pembelajaran daring merupakan sesuatu yang baru bagi guru. Faktor penghambat tersebut diantaranya belum semua peserta didik memiliki handphone. Faktor yang selanjutnya adalah rasa malas pada peserta didik pada saat mengerjakan tugas, mekipun sudah didukung dengan fasilitas yang menunjang pembelajaran, faktor yang selanjutnya adalah masih banyak orang tua yang bekerja sehingga tidak dapat sepenuhnya membimbing peserta didik dalam pembelajaran. tidak heran jika ada siswa yang tidak memahami materi pelajaran, sebagimana data pada gambar 4 di atas, yaitu hasilnya kurang baik. Sebagian besar dari mereka 4 orang siswa ( $18,2 \%)$, menjawab selalu, 3 orang siswa atau ( $13,6 \%)$ menjawab sering, 6 atau ( $27,3 \%$ ) orang siswa menjawab jarang, kadang-kadang 7 ( $31,6 \%)$ orang siswa dan 2 atau $(9,1 \%)$ orang siswa menjawab tidak pernah.

Ada beberapa cara untuk mengatasi hambatan tersebut, diantaranya adalah guru di SMK Dharma Bhakti Kota Tangerang memberikan informasi di awal sebelum pembelajaran dilaksanakan. Informasi di awal pembelajaran menjadikan siswa siap mengikuti pembelajaran. sudah berusaha mencari bahan-bahan lain lewat google misalnya yang kaya akan berbagai informasi, termasuk materi-materi yang akan di ajarkan guru.

Usaha lainnya adalah melakukan kerjasama dengan komite sekolah. Mendata kedua orang tua yang bekerja, guru memberikan pelonggaran 59 | Akademika | Vol 10 | No. 1 | 2021 
dalam pengumpulan tugas tidak tepat pada waktunya, yang penting tugasnya dikerjakan. Kemudian juga mendata alamat tinggal para peserta didik, agar mereka yang jarak rumahnya berdekatan, dapat saling membantu, khususnya teman yang belum memiliki handphone untuk dapat sama sama mengikuti pembelajaran dengan teman yang memiliki handpone.

Salah satu keberhasilan dari kegiatan belajar dapat dilihat melalui hasil belajar siswa. Hasil belajar yang belum memuaskan di atas bisa jadi didukung oleh adanya perbedaan gaya belajar tiap siswa yang berbeda sehingga dalam menerima, mengolah dan mengingat informasi yang diperoleh juga berbedabeda. Selama ini guru kurang menyadari hal ini, sehingga ketika proses belajar berlangsung guru kurang memperhatikan jenis gaya belajar yang dimiliki siswa. Ada tiga jenis gaya belajar, yaitu: 1) gaya belajar visual; 2) gaya belajar auditorial; dan 3) gaya belajar kinestetik (Widayanti, 2013).

\section{Efektifitas WhatsApp group sebagai media belajar daring pada mata pelajaran Pendidikan Agama Islam selama darurat Covid-19 di SMK Dharma Bhakti Kota Tangerang}

Pembelajaran daring tidak efektif apabila diterapkan pada sekolah yang infrastrukturnya belum memadai, (belum memiliki perangkat wifi ). Pembelajaran daring berbasis teknologi memerlukan pendekatan yang berbeda dalam hal perencanaan, pelaksana dan evaluasinya. Pelaksanaan pembelajaran daring, peserta didik membutuhkan perhatian khusus, terutama sarana prasarana yang digunakan, jaringan internet yang memadai dan motivasi diri agar dapat mengikuti proses pembelajaran yang bersifat mandiri. Sistem pembelajaran daring saat ini masih menjadi beban bagi para guru, para orang tua siswa dan para siswa. Sistem pembelajaran daring hanya efektif untuk penugasan. Hal ini didukung oleh data pada gambar 5 di atas, dari total responden 22 orang yang menjawab selalu sebanyak $5(22,7 \%)$ yang menjawab sering sebanyak 10 $(45,5 \%)$, jarang $2(9,1 \%)$, kadang-kadang $3(13,6 \%)$ dan tidak pernah sebanyak $2(9,1 \%)$. Dapat disimpulkan kendala terbesar pada siswa selama pembelajaran daring adalah kurang suport kuota.

Menyadari keterbatasan inilah makanya di SMK Dharma Bhakti Kota Tangerang memilih menggunakan media WhatsApp grub dalam berkomukasi dan sebagai media interaktif dengan siswa, relative lebih hemat paket data yang dibutuhkan. Tidak seperti halnya media zoom meeting dan google meeting yang membutuhkan kuota internet besar. Menurut Putranti pembuatan media pembelajaran online perlu mempertimbangkan harapan dan tujuan mereka dalam mengikuti media pembelajaran online, kecepatan dalam mengakses internet atau jaringan, keterbatasan bandwidth, biaya untuk akses internet, serta latar belakang pengetahuan yang menyangkut kesiapan dalam mengikuti pembelajaran (Putranti, 2013)

SMK Dharma Bhakti Kota Tangerang sangat memperhatikan kondisi ekonomi para orang tua dan siswa yang terdampak pandemi Covid-19, sistem pembelajaran daring masih menjadi pilihan, maka berharap pemerintah memberikan bantuan yang simultan pada siswa dan guru, sehingga sesekali dapat dilakasanakan pembelajaran dengan bantuan zoom meeting dan google classroom yang aplikasinya tentu lebih lebih banyak siswa yang bisa masuk ke dalam kelas online dibandingkan WhatsApp yang hanya terbatas 5-8 orang saja. 
Sistem pembelajaran daring yang dilaksanakan dalam beberapa bulan terakhir ini dengan media WhatsApp belum benar-benar efektif. Namun demikian dari Diagram $1 \mathrm{di}$ atas terlihat bahwa nilai siswa selama masa Covid-19 ini, lebih meningkat 50\% menggunakan WhatsApp di bandingkan dengan tanpa menggunakan WhatsApp. Meskipun dalam angket yang diisi oleh siswa menyatakan bahwa mereka mendapatkan kendala kuota internet dalam pembelajaran daring, namun media ini tetap lebih efektif bagi mereka di bandingkan dengan media lain, seperti zoom meeting yang kuota internetnya tentu lebih besar lagi.

Adapun yang menjadi kekurangan / kelemahan pembelajaran daring di di SMK Dharma Bhakti Kota Tangerang adalah kurang maksimalnya keterlibatan siswa. Keterlibatan siswa yang dimaksud dapat dilihat dari hasil keterlibatan siswa dalam mengikuti pembelajaran daring secara penuh dari awal pembelajaran sampai akhir pembelajaran. kejujuran dan kemandirian siswa dalam mengerjakan tugas kurang terkontrol.

Covid-19 memaksa kita untuk tetap di rumah saja. Media sosial WhatsApp menjadi pilihan bagi guru di SMK Dharma Bhakti. Memaksa guru menggunakan media yang familiar digunakan, tentu media tidak mempersulit siswa dalam penggunaannya. Media yang menjadikan proses KBM tetap berjalan, meskipun ada kekurangan media ini yang menjadikan belum efektifnya hasil pembelajarannya.

Pemilihan media yang efektif dan tepat ini didukung oleh pendapat Musfiqon bahwa Ada tiga prinsip utama yang bisa dijadikan rujukan bagi guru dalam memilih media pembelajaran yaitu: 1) Prinsip efektifitas, dalam konsep pembelajaran, efektifitas adalah keberhasilan pembelajaran yang diukur dari tingkat ketercapaian tujuan setelah pembelajaran selesai dilaksanakan 2) Relevansi, guru dituntut untuk bisa memilih media yang sesuai dengan tujuan, isi, metode dan evaluasi pembelajaran, 3) Produktifitas, dalam memilih media pembelajaran guru dituntut untuk bisa menganalisis apakah media yang digunakan bisa meningkatkan pencapaian tujuan pembelajar atau tidak ( Musfiqon:2012). Hal ini sejalan dengan hasil penelitian Khasanah dan Heryanti menyatakan Secara keseluruhan terdapat pengaruh interaksi bahan ajar dengan kreatifitas belajar siswa dalam mata pelajaran Ilmu Pengetahuan Alam (Khasanah \& Heryanti, 2017)

Adapun kelebihan-kelebihan WhatsApp sebagai media pembelajaran 1) Tidak harus login terlebih dahulu untuk mengakses WhatsApp jika nomor ponsel sudah terdaftar, 2) Langsung terhubung dengan kontak pengguna WhatsApp lainnya, Pengguna dapat bertukar kontak dengan pengguna lainnya, 3) Dapat membagikan lokasi terkini, Dapat mengirim pesan ke banyak orang (broadcast), 4) Aplikasi ini tidak menguras kuota terlalu banyak, 5) Guru dan siswa dapat berdiskusi dan bertanya jawab dengan lebih rileks, 6) Dapat melihat siapa saja yang sudah membaca dan siapa yang tidak aktif, 7) Guru dapat mengirimkan dokumen, foto, audio ataupun video sebagai materi pembelajaran kepada siswa melalui grup WhatsApp, 8) Guru dan siswa dapat melihat dan mengulang materi pembelajaran melalui HP dengan mudah, 9) Guru dan siswa dapat berkomunikasi kapan saja dan di mana saja.

Untuk mencapai tujuan pembelajaran dari pelajaran PAI ini, maka SMK yang kami teliti ini terus melakukan upaya-upaya pemilihan media yang tepat ini, 61 | Akademika | Vol 10 | No. 1 | 2021 
meskipun setelah dievaluasi masih ada hamper setengah dari siswa belum meningkat hasil belajarnya. Efektivitas secara umum menunjukkan sampai seberapa jauh tercapainya tujuan pembelajaran yang telah ditentukan (Müller et al., 2019) Efektivitas adalah suatu ukuran yang menyatakan seberapa jauh target (kuantitas, kualitas dan waktu) telah tercapai, atau semakin besar presentase target yang dicapai, makin tinggi efektivitasnya .Semakin banyak rencana yang dapat dicapai, semakin efektif pula kegiatan tersebut, sehingga kata efektivitas dapat juga diartikan sebagai tingkat keberhasilan yang dapat dicapai dari suatu cara atau usaha tertentu sesuai dengan tujuan yang hendak dicapai. Efektivitas adalah suatu ukuran yang menyatakan seberapa jauh target (kuantitas, kualitas dan waktu) telah tercapai, atau semakin besar presentase target yang dicapai, makin tinggi efektivitasnya (Rohmawati, 2015).

Prinsip pokok yang harus diperhatikan dalam penggunaan media pada setiap kegiatan belajar mengajar adalah bahwa media digunakan dan diarahkan untuk mempermudah siswa belajar dalam upaya memahami materi pelajaran. Dengan demikian penggunaan media harus dipandang dari sudut kebutuhan siswa. Hasil Penelitian Musa dan Khasanah menyatakan bahwa proses pembelajaran prakarya dan kewirausahaan yakni perlunya memilih media pembelajaran yang tepat di kelas X SMA almuslim Tambun Bekasi khususnya dalam mempelajari mata pelajaran prakarya dan kewirausahaan. Alasannya dengan menggunakan media pembelajaran e learning berbasis moodleyang tepat terhadap materi yang diajarkan diharapkan guru dapat meningkatkan hasil belajar dan peran aktif siswa dalam mengikuti pelajaran prakarya (Musa \& Khasanah, 2019)

Hal ini perlu ditekankan sebab sering media dipersiapkan hanya dilihat dari sudut kebutuhan siswa. Agar media pembelajaran benar-benar digunakan untuk membelajarkan siswa maka ada sejumlah prinsip yang harus diperhatikan, diantaranya: 1) Media yang digunakan oleh guru harus sesuai dan diarahkan untuk mencapai tujuan pembelajaran. 2) Media yang digunakan harus sesuai dengan materi pembelajaran. 3) Media pembelajaran harus sesuai dengan minat, kebutuhan dan kondisi siswa. 4) Media yang digunakan harus memerlukan efektivitas dan efisien. 5) Media yang digunakan harus sesuai dengan kemampuan guru dalam mengoperasikannya.

Hal ini sejalan juga dengan Penelitian (Jamaluddin et al., 2020) merumuskan simpulan bahwa dalam pandemi Covid-19, pembelajaran dalam jaringan (daring) dapat digunakan dengan pertimbangan memperhatikan kondisi mahasiswa dan dosen, sehingga akan terbiasa menyesuaikan dengan sistem daring, pembelajaran dapat terlaksana dengan baik. Selain itu, sistem daring ini dapat dijadikan pengalaman tambahan bagi mahasiswa sebagai calon guru di masa depan.

Syarifudin (2020) melakukan penelitan lain nya menyatakan bahwa pembelajaran daring merupakan pembelajaran yang dilakukan menggunakan internet sebagai tempat menyalurkan ilmu pengetahuan. Bentuk pembelajran sepertii ini dapat dilakukan kapanpun dan dimanapun tanpa terikat waktu dan tanpa harus bertatap muka. Di era perkembangan teknologi pembelajaran daring semakin canggih dengan berbagai aplikasi dan fitur yang semakin memudahkan pengguna. Tidak terikatnya waktu dan dialkukan tanpa bertatap muka menjadi keunggulan pembelajaran daring yang biasa dimanfaatkan pendidik. 
pembelajaran daring dapat dikatakan menjadi satu-satunya pilihan pembelajaran yang dapat dilakukan oleh pendidik untuk menigkatkan mutu pembelajaran di Indonesia (Syarifudin, 2020)

Peranan media WhatsApp group sebagai media pendukung pembelajaran daring di sekolah: 1) Media sosial WhatsApp menjadi media belajar yang cukup membantu mempermudah pekerjaan menjadi lebih cepat dan gampang, penggunaannya menjadi sangat penting karena menghemat waktu. 2) Media sosial WhatsApp bisa dibilang kurang efektif karena materi yang disampaikan sulit diserap oleh siswa karena tidak dijelaskan secara langsung tergantung cara guru menyampaikan dan siswa yang menerima. Ada beberapa anak yang mudah mengerti dan ada juga yang tidak, secara teori materi bisa tersampaikan dengan baik lewat WhatsApp, namun untuk praktik, pertemuan tatap muka tetap harus dilakukan.

Hambatan dalam menggunakan WhatsApp sebagai media pembelajaran yang paling sering ditemui adalah siswa yang jarang membuka grup kelas atau tidak memiliki paket internet. Siswa juga sulit memahami materi yang dikirimkan dan kebanyakan siswa memilih lebih baik melakukan tatap muka karena lebih mudah mendengarkan penjelasan secara langsung. Guru juga tidak bisa memantau secara langsung keseriusan siswa dalam mengerjakan tugas yang diberikan.

\section{KESIMPULAN}

Berdasarkan penelitian yang telah dilakukan, peneliti dapat mengambil beberapa kesimpulan dalam rangka memutus mata rantai penyebaran Covid-19 di lingkungan sekolah SMK Dharma Bhakti Kota Tangerang, yaitu : Media sosial WhatsApp digunakan sebagai media pembelajaran menjadi media yang mempunyai peran penting dalam proses belajar mengajar Dengan adanya WhatsApp, guru-guru menjadi lebih terbantu mempermudah pekerjaan menjadi lebih cepat dan gampang. Materi yang belum selesai dikirimkan lewat WhatsApp dengan cepat.

WhatsApp penting dalam proses belajar mengajar, dengan berbagai fitur yang dimiliki, WhatsApp membantu mengumpulkan tugas. Akan tetapi, dalam proses belajar mengajar, penggunaan WhatsApp kurang efektif karena anakanak tidak mampu memahami materi yang disampaikan, terkendala dengan masalah kuota. Akan lebih baik jika WhatsApp hanya dijadikan sebagai medianya saja, guru dan siswa yang bersangkutan harus tetap menunaikan kewajiban dalam belajar dan mengajar agar materi dan tugas dapat tersampaikan dan diserap dengan baik.

Penggunaan WhatsApp secara massif di sekolah, termasuk guru dan siswa di SMK Dharma Bhakti Kota Tangerang, perlu adanya peningkatan fasilitas yang mendukung untuk penggunaan media sosial WhatsApp sebagai media pembelajaran seperti laptop, LCD, dan speaker di kelas agar bisa difungsikan dengan baik dan maksimal.

Pembelajaran daring ini perlu dievaluasi secara menyeluruh. Kapasitas, kesiapan guru dan siswa serta kemampuan orang tua mesti menjadi bahan pertimbangan yang penting. Perlu upaya serius dari semua pihak untuk membangun sistem pembelajaran daring yang efektif. 


\section{DAFTAR PUSTAKA}

Anhusadar, L. O. (2020). Efektivitas Pembelajaran Online Pendidik PAUD di Tengah Pandemi Covid 19. Jurnal Obsesi : Jurnal Pendidikan Anak Usia Dini, 5(1), 686-697. https://doi.org/10.31004/obsesi.v5i1.699.

Bilfaqih.Y, \& Qomarudin. M. N. ( 2015 ). Esensi Penyusunan materi pembelajaran daring, panduan berstandar penyusunan materi pembelajaran daring untuk pendidikan dan pelatihan.Yogyakarta :Deepublish.

Daud, D. (2020). Social Distancing dan Budaya Kita. Pandemik COVID-19 Persoalan Dan Refleksi, May, 39-47.

Di, P. C.-, \& Nurulhuda, M. I. (2020). Pemanfaatan Media Pembelajaran ELearning Menggunakan Whastsapp Sebagai Solusi Ditengah Penyebaran Covid-19 Di Mi Nurulhuda Jelu. 6(2), 144-159.

Handarini, O. I., \& Wulandari, S. S. (2020). Pembelajaran Daring Sebagai Upaya Study From Home (SFH) Selama Pandemi Covid 19. Jurnal Pendidikan Administrasi Perkantoran (JPAP), 8(3), 496-503.

Herliandry, L. D., Nurhasanah, Suban, M. E., \& Heru, K. (2020a). Pandemic learning during the Covid-19. Jurnal Teknologi Pendidikan, 22(1), 65-70. https://doi.org/https://doi.org/10. 21009/jtp.v22i1.15286.

Hayes, C., Hardian, H., \& Sumekar, T. (2017). Pengaruh Brain Training Terhadap Tingkat Inteligensia Pada Kelompok Usia Dewasa Muda. Diponegoro Medical Journal (Jurnal Kedokteran Diponegoro), 6(2), 402416.

Jamaluddin, D., Ratnasih, T., Gunawan, H., \& Paujiah, E. (2020). Pembelajaran Daring Masa Pandemik Covid-19 Pada Calon Guru : Hambatan, Solusi dan Proyeksi. Karya Tulis IImiah UIN Sunan Gunung Djjati Bandung, 1-10. http://digilib.uinsgd.ac.id/30518/

Müller, C., Stahl, M., Alder, M., \& Müller, M. (2019). Learning Effectiveness and Students' Perceptions in A Flexible Learning Course. European Journal of Open, Distance and E-Learning, 21(2), 44-52. https://doi.org/10.2478/eurodl-2018-0006

Mirzon Daheri, Juliana, Deriwanto, A. D. A. (2020). Jurnal basicedu. Jurnal Basicedu, 3(2), 524-532. https://doi.org/10.31004/basicedu.v4i4.445

NA, M., \& M. Pd, K. (2019). Pengaruh Penggunaan Media E-Learning Berbasis Moodle Dan Minat Belajar Terhadap Hasil Belajar Prakarya Dan Kewirausahaan. Akademika, 8(01), 1-16. https://doi.org/10.34005/akademika.v8i01.332

Rachmat, A., \& Krisnadi, I. (2020). Analisis Efektifitas Pembelajaran Daring (Online) Untuk Siswa SMK Negeri 8 Kota Tangerang Pada Saat Pandemi Covid 19.

Rohmawati, A. (2015). Efektivitas Pembelajaran. Jurnal Pendidikan Usia Dini, $9(1), 15-32$.

Riduwan (2018) Metode dan Teknik Menyusun Tesis. Alfabet. Bandung

Syarifudin, A. S. (2020). Impelementasi Pembelajaran Daring Untuk Meningkatkan Mutu Pendidikan Sebagai Dampak Diterapkannya Social Distancing. Jurnal Pendidikan Bahasa Dan Sastra Indonesia Metalingua, 5(1), 31-34. https://doi.org/10.21107/metalingua.v5i1.7072

Suhendra, A. D., Asworowati, R. D., \& Ismawati, T. (2020). Pembelajaran Daring 
Di Tengah Wabah Pandemi Covid-19 Di Universirtas Abdurachman Saleh Situbondo. Akrab Juara, 5(1), 43-54.

http://www.akrabjuara.com/index.php/akrabjuara/article/view/919.

Susilowati, E. (2020). Bagaimana Pembelajaran Daring di Tengah Wabah Covid 19 melalui Grup WhatsApp ? Jurnal Pendidikan Matematika Raflesia, 05(03), 1-25.

S.Pd, K., \& Heryanti, N. (2017). Pengaruh Pemanfaatan Bahan Ajar Audio Visual Dan Kreativitas Belajar Terhadap Hasil Belajar Ilmu Pengetahuan Alam. Akademika, 6(02), 1-16. https://doi.org/10.34005/akademika.v6i02.139

Wahyuni, N. (2018). Peran Penggunaan Grup WhatsApp Dalam Proses Belajar Mengajar Di Smk Negeri 2 Banjarmasin. 1(2).

Widayanti, F. D. (2013). Pentingnya Mengetahui Gaya Belajar Siswa Dalam Kegiatan Pembelajaran Di Kelas. Erudio Journal of Educational Innovation, 2(1). https://doi.org/10.18551/erudio.2-1.2 